\title{
Seroprevalence of Human Immunodeficiency Virus, Hepatitis C Virus and Hepatitis B Virus in Police Personals
}

\author{
Priyanka Khanna, Jaspal Kaur* and Kailash Chand
}

\author{
Department of Microbiology, PIMS Medical College, Jalandhar, Punjab, India \\ *Corresponding author
}

A B S T R A C T

\begin{tabular}{|l|}
\hline Key w or d s \\
HIV (Human \\
Immunodeficiency \\
virus), HCV, \\
HBsAg, Police \\
personnels.
\end{tabular}

The study was conducted at PIMS (Punjab Institute of Medical sciences) at Jalandhar from January 2016 to April 2016. In the present study, 2500 police personnel were screened for blood borne infections namely HIV, HCV and HBV. 2220 (88.8\%) were males and 280 (11.2\%) were females amongst them. According to age distribution, the maximum personnel i.e. 1870 (74.8\%) belonged to the age group of $21-30$ years followed by3140 years (12\%), 41-50 years $(9 \%)$ and $>50$ years $(3.4 \%)$. Out of total 2500 personnel, prevalence of HIV reactive was found to be $0.4 \%$, HCV reactive was found to be $1.16 \%$ and $\mathrm{HBs} \mathrm{Ag}$ was $0.5 \%$. The study revealed that in HIV reactive cases 10 were males and only 1 case of female. 22 males and 7 females were found to be reactive in $\mathrm{HCV}$ and in HBs Ag there were 7 males and only 1 was female. In our study, we found that the prevalence of $\mathrm{HIV}$ and $\mathrm{HCV}$ was more predominant in females $(0.71 \%$ and $2.5 \%)$ as compared to males $(0.45 \%$ and $0.99 \%)$. The prevalence of $\mathrm{HBs} \mathrm{Ag}$ in females was slightly more $(0.35 \%)$ as compared to males $(0.31 \%)$.

\section{Introduction}

Police personnel, who are usually first responders to any casualty, have the potential for occupational exposure to blood, which increases their risk for blood-borne infections such as HIV (Human Immunodeficiency Virus), HCV (Hepatitis C Virus) and HBV or HBs Ag (Hepatitis B Virus) etc. Therefore a higher prevalence might be seen in this group as compared to the general population.

Regular monitoring of the information in the form of annual examination on high-risk behaviours and prevalence in this group is strongly recommended. First confirmed case of AIDS was identified in 1983 and by 1984 the etiologic agent, the Human
Immunodeficiency Virus (HIV), subsequently named HIV-1 was isolated. Shortly afterwards in 1985 another retrovirus subsequently named HIV-2 was isolated in Africa. These two viruses belong to the retrovirus group and are slow viruses.

HIV/AIDS has had a great impact on society, both as an illness and as a source of discrimination. The disease also has large economic impacts. There are many misconceptions about HIV/AIDS such as the belief that it can be transmitted by casual nonsexual contact. There is no cure or vaccine available as on date, however, antiretroviral treatment can slow the course of the disease 
and may lead to a near-normal life expectancy. Treatment is recommended as soon as the diagnosis is made. Without treatment, the average survival time after infection may be around 10 years.

Hepatitis C Virus (HCV) was identified in 1989 as the main aetiological agent of non-A, non-B hepatitis (NANBH) accounting for greater than $90 \%$ of post-transfusion hepatitis cases. Hepatitis C Virus (HCV) is a flavi virus which belongs to Flaviviridae family. It is now the commonest cause of post-transfusion hepatitis in the various developed countries. Hepatitis $\mathrm{C}$ is an infection that mostly affects the liver. Often, a person with Hepatitis C does not have any symptoms. However, chronic infection can scar the liver. Many years of infection may cause cirrhosis. Sometimes, people with cirrhosis also have liver failure or liver cancer. They can also have very swollen veins of the oesophagus and stomach. The blood loss from this problem can kill. Around the world, about 130-170 million people have Hepatitis C. Scientists began studying the Hepatitis C virus in the 1970s, and in 1989 they proved that the virus exists. As far as scientists know, this virus does not cause disease in any animals other than humans. The medications that are normally used to treat Hepatitis $\mathrm{C}$ are called peg interferon and ribavirin. Between $50-80 \%$ of people who are treated (5 to 8 out of every 10) are cured. However, if a person's Hepatitis $\mathrm{C}$ has progressed (or gotten worse) so much that the person has cirrhosis or liver cancer, the person might need a liver transplant. This makes it possible for the person to survive, but the Hepatitis $\mathrm{C}$ virus usually comes back after the transplant. There is no vaccine that works to prevent people from getting Hepatitis C.

Hepatitis $\mathrm{B}$ virus (HBV) is a member of the hepadnavirus family. HBs Ag (also known as the Australia antigen) is the surface antigen of the hepatitis B virus (HBV). It indicates current hepatitis B infection. This is because it was first isolated by the American research physician and Nobel Prize winner Baruch S. Blumberg in the serum of an Australian Aboriginal person. It was discovered to be part of the virus that caused serum hepatitis by virologist Alfred Prince in 1968.

The infection can be diagnosed 30 to 60 days after exposure. Diagnosis is typically by testing the blood for parts of the virus and for antibodies against the virus. It is one of five known hepatitis viruses i.e. A, B, C, D, and E.

\section{Risk factors of HIV, HCV and HBs Ag infections}

Sharing drug needles or syringes.

Sexual contact (including oral, anal or vaginal sex) with someone who is HIV, HCV and HBs Ag positive or whose HIV, HCV and HBs Ag status is unknown, without the protection of a latex condom.

Having another sexually transmitted disease such as syphilis, herpes, chlamydial infection, gonorrhoea or bacterial vaginosis seems to increase the risk of being infected by HIV, $\mathrm{HCV}$ and $\mathrm{HBs}$ Ag during unprotected sexual contact with an infected partner.

Babies can be infected by the mother (positive case) during pregnancy or breast feeding.

The person may be of any status, rich or poor, young or old, black or white, gay or straight, married or single, it's what person do, not who person is, that puts a person at risk.

\section{Sign and symptoms of the infection}

Many people have no symptoms of any of these infections; symptoms are usually vague to start with such as flu-like symptoms a 
month or two after getting these viral infections. Others may include fever, headache, tiredness, and enlarged reticuloendothelial organs. Further symptomatology depends upon the stage of the disease.

\section{Aims and objectives}

The aim and objective of the study is to evaluate the prevalence of various viral infections namely $\mathrm{HIV}, \mathrm{HCV}$ and $\mathrm{HBs} \mathrm{Ag}$ usually transmitted through sexual route/ body fluids in the blood samples of serving police personnel in Punjab during their annual medical examinations.

\section{Materials and Methods}

The current study was conducted in Microbiology department of Punjab Institute of Medical Sciences, Jalandhar during the period of $1^{\text {st }}$ January 2016 to $25^{\text {th }}$ March 2016. Blood samples of 2500 police personnel were taken. Sera was separated and screened for HIV, HCV and HBs Ag by rapid test method.

\section{HIV}

The Tri Dot test is manufactured by J. Mitra $\&$ Sons of India, and was developed specifically for the Indian market.

The test is named for the three dots that appear to give the result: one pink dot is a control dot, showing the test is functioning properly; one dot shows the presence of HIV1 antibodies and one dot shows the presence of HIV-2 antibodies.

HIV TRI-DOT kit was used to test the antibodies detection against HIV-1 and HIV2 in serum samples of the healthy serving police personnel. This is a rapid Visual Test for the Qualitative detection of Antibodies to HIV-1 \& HIV-2 in Human Serum/Plasma.

\section{HCV}

For the detection of Hepatitis C Virus, we used HCV TRI-DOT (Rapid Visual Test) for the Qualitative Detection of Antibodies to HEPATITIS $\mathrm{C}$ Virus in Human Serum/Plasma manufactured by J. Mitra \& Sons of India.

\section{HBs Ag}

For the detection of hepatitis B virus, we prefer to HEPACARD.

One Step Rapid Visual Test for the Qualitative Detection of HBs Ag in Human Serum/Plasma.

HEPACARD is a one step immunoassay based on the antigen capture, or "sandwich" principle. The method uses monoclonal antibodies conjugated to colloidal gold and polyclonal antibodies immobilized on a nitrocellulose strip in a thin line. The test sample is introduced to and flows laterally through an absorbent pad where it mixes with the signal reagent. If the sample contains HBs $\mathrm{Ag}$, the colloidal gold-antibody conjugate binds to the antigen, forming an antigenantibody- colloidal gold complex. The complex then migrates through the nitrocellulose strip by capillary action. When the complex meets the line of immobilized antibody (Test line) "T", the complex is trapped forming an antibody-antigen-colloidal gold complex. This form a pink band indicating the sample is reactive for $\mathrm{HBs} \mathrm{Ag}$. To serve as a procedural control, an additional line of anti-mouse antibody (Control line) ' $\mathrm{C}$ ', has been immobilized at a distance from the test line on the strip. If the test is performed correctly, this will result in the formation of a pink band upon contact with the conjugate.

During the entire training period i.e. from $1^{\text {st }}$ January to $25^{\text {th }}$ March at PIMS (Punjab 
Institute of Medical Sciences) Hospital, Jalandhar, the clinical specimens were obtained from the in-service police personnel at Jalandhar. A total of 2500 samples have been processed. Out of these 2220 were from male and 280 from the female police personnel.

\section{Results and Discussion}

Our study has aimed at determining the seroprevalence of $\mathrm{HBV}, \mathrm{HCV}$ and $\mathrm{HIV}$ among Police personnel because they are usually the first responders to any casualty, have the potential for occupational exposure to blood, which increases their risk for bloodborne infections such as HIV, Hepatitis C and Hepatitis B etc. Therefore a higher prevalence might be seen in this group as compared to the general population.

In the present study, we have screened 2500 police personnel, in which 2220 (88.8\%) were males and $280(11.2 \%)$ were females (Table 1). According to age distribution, the maximum personnel i.e. $1870 \quad(74.8 \%)$ belonged to the age group of 21-30 years followed by 31-40 years (12\%), 41-50 years $(9 \%)$ and $>50$ years $(3.4 \%)$ (Table 2 ).

Out of total 2500 personnel, prevalence of HIV reactive was found to be $0.4 \%$ (11),
$\mathrm{HCV}$ reactive was found to be $1.16 \%$ (29) and HBs Ag was $0.5 \%$ (12).

The study conducted by Kapur et al., at Delhi in 8 years period revealed the overall HIV seroprevalence of $0.68 \%$, which was slightly higher than our incidence $(0.4 \%)$. The seroprevalence of $\mathrm{HBs} \mathrm{Ag}$ was $1.2 \%$ in the same study.

Sarin et al., (1998) at New Delhi conducted a study in which the seroprevalence of HIV was $0.5 \%$ and on other side the same study was conducted by Joshi et al., where the seroprevalence of HIV was $0.47 \%$. Both of the study correlated with our study in which the HIV seroprevalence is $0.4 \%$.

A similar study conducted by Kulkarni et.al at Bombay, Ramanamma et al., at Vishakapatnam and Shashikala et al., at North Karnataka observed HIV seroprevalence was $1.3 \%, 5.06 \%$ and $1.74 \%$ respectively.

The incidence of HIV was much higher as compared to our incidence $(0.4 \%)$.

Allain Pierre Jean et al., conducted a study in which the seroprevalence of $\mathrm{HCV}$ was $0.28 \%$. Desphande et al., observed the similar study in which the seroprevalence of $\mathrm{HCV}$ was $0.35 \%$, which is less than the current study.

Table.1 Most of the personnel belonged to age group 21-30 years (75\%)

\begin{tabular}{|l|l|l|l|l|l|l|}
\hline & HIV & Percentage & HCV & Percentage & HBsAg & Percentage \\
\hline Reactive & 11 & 0.4 & 29 & 1.16 & 12 & 0.5 \\
\hline Non-Reactive & 2489 & 99.6 & 2471 & 98.84 & 2488 & 99.5 \\
\hline Total & 2500 & 100 & 2500 & 100 & 2500 & 100 \\
\hline
\end{tabular}

Table.2 The concurrent infection of only HIV with HCV was found in 2 out of 2500 personnel. No incidence of any other concurrent infection

\begin{tabular}{|c|c|c|c|}
\hline & $\mathrm{HIV}+\mathrm{HCV}$ & $\mathrm{HCV}+\mathrm{HBs} \mathrm{Ag}$ & $\mathrm{HIV}+\mathrm{HBs} \mathrm{Ag}$ \\
No. & 2 & 0 & 0 \\
$\%$ age & $0.08 \%$ & 0 & 0 \\
\hline
\end{tabular}




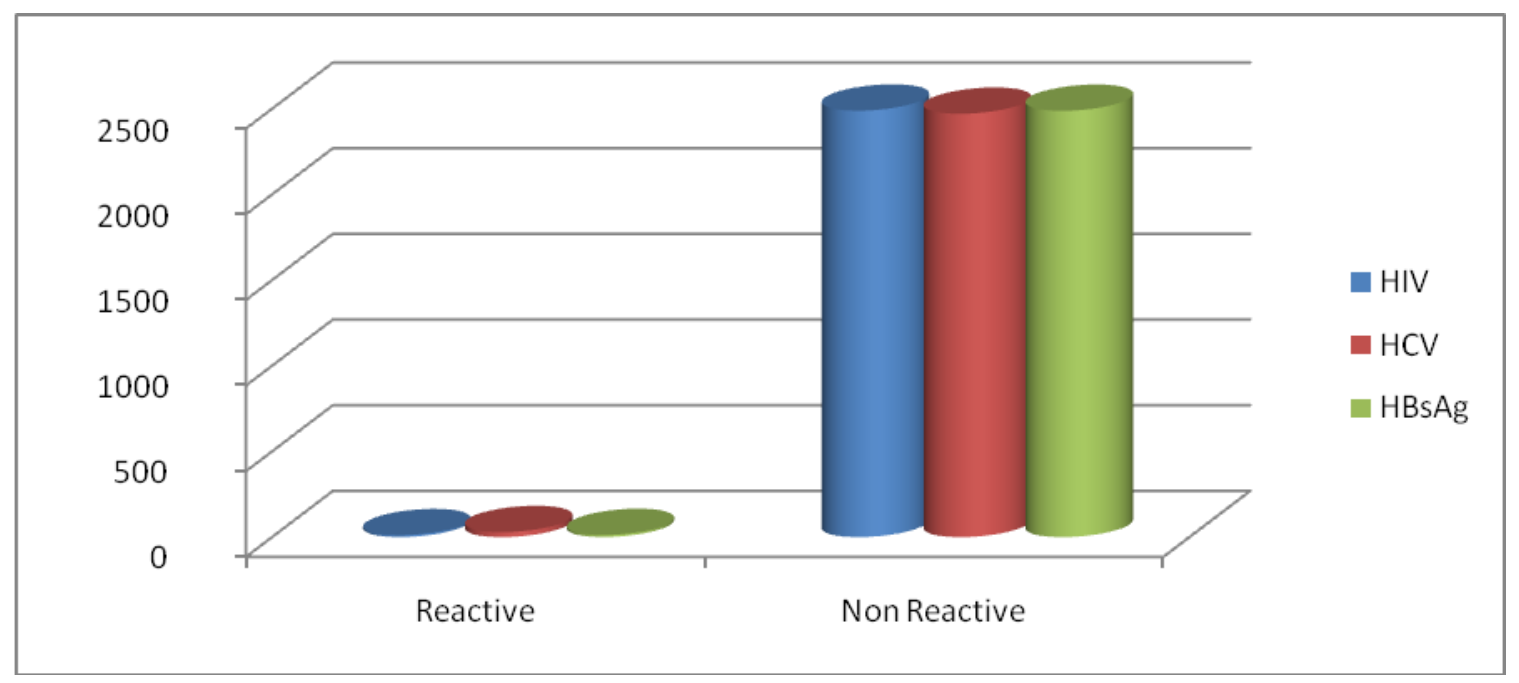

Various studies in India about the seroprevalence of $\mathrm{HCV}$ have shown data ranging from the lowest $(0.31 \%)$ in the study by Bhattacharya et al., in 2007 to the higher one of $1.09 \%$ (Gupta et al., 2004).

India has been placed in the intermediate zone of prevalence of hepatitis B by the World Health Organization (2-7\% prevalence rates) with a HB sAg prevalence rate of 1-2\% reported by Lodha et al., supporting this, HBs $\mathrm{Ag}$ prevalence in Punjab blood donors was 1.7\%, while Rajasthan had $3.44 \%$ and Delhi had 2.23\%. In Karnataka, coastal area had $0.62 \%$ and Bangalore had $1.86 \%$ of HBV seropositivity. Our study revealed the prevalence of $\mathrm{HBs} \mathrm{Ag}$ as $0.5 \%$ which is similar to study done at Karnataka.

KishanRao conducted a study on seroprevalence of HIV, Hepatitis B \& C viruses in healthy voluntary blood donors of college going students $(16-25$ years $)$ in 2014, A.P. The study revealed $79.7 \%$ were males and $20.3 \%$ were females. HBs Ag was positive in $1.68 \%, \mathrm{HCV}$ was positive in $0.84 \%$ (near about $1 \%$ ) HIV was positive $0.42 \%$. These findings are in agreement with our present study. In our study prevalence of $\mathrm{HBs} \mathrm{Ag}, \mathrm{HCV}$ and $\mathrm{HIV}$ was $0.5 \%, 1.16 \%$ and $0.4 \%$ respectively. So this study is in correlation with our study according the distribution of gender wise also where maximum incidence of positive cases was found to be in age group 21-25 years.

The study conducted by Pallavi et al., on the blood donors for four years period between 2004 and 2008 at JSS Hospital, Mysore also revealed the similar results showing prevalence of $\mathrm{HIV}, \mathrm{HCV}$ and $\mathrm{HBs} \mathrm{Ag}$ of $0.44 \%, 1.27 \%$ and $0.23 \%$ respectively which is strongly same as our study.

A study was conducted by Dr. Arora et al., to find out the seroprevalence of HIV, HCV and HBs Ag in blood donors in southern Haryana at the blood transfusion centre of Maharaja Agrasen Medical College, Agroha (Hisar) in 2010. The seroprevalence of HIV, HCV and HBs $\mathrm{Ag}$ was found to be $0.3 \%, 1.7 \%$ and $1.0 \%$ respectively in total donors and in our study the prevalence of HIV, HCV and HBV is $0.4 \%, 1.16 \%$ and $0.5 \%$ respectively.

In a similar study conducted by Datta on seroprevalence of Hepatitis B, Hepatitis C, and HIV among healthy voluntary first-time blood donors in Kolkata which is in correlation with our study, a total of 3745 voluntary first-time blood donors were studied. Among the three viruses, prevalence wise, HBV outnumbered the other two. Prevalence of $\mathrm{HBV}$ was $1.55 \%$, whereas 
HCV and HIV were $0.35 \%$ and $0.32 \%$, respectively. In our study no such increased incidence of HBV was found. The study population was divided into four groups according to their age and found that most of the donors were within 18 to 29 years age group correlating with our study where the most of the personnel were within 21 to 30 years age group.

A study about Hepatitis B and C Viral Infections among Blood Donors from Rural Ghana, conducted by B Nkrumah et al., a total of 2773 prospective blood donors were screened from January 2006 to December 2008. Out of this $92.2 \%$ were males and $7.8 \%$ were females. Majority of the study population $43.9 \%$ were in the 26 to 35 age group of the total number. The seroprevalence of $\mathrm{HBV}, \mathrm{HCV}$ and both $(\mathrm{HBV}+\mathrm{HCV})$ was $10.53 \%, \quad 5.63 \%$ and $2.09 \%$ positive respectively. The seroprevalence of this study was higher than our study which can be attributed to rural background and the poor socioeconomic status of this country. In our study the seroprevalence of $\mathrm{HBV}$ is $0.5 \%$, HCV $1.16 \%$ and there was no case was found of concurrent $\mathrm{HBV}$ and $\mathrm{HCV}$. Concurrent infection of only HIV with HCV was found in 2 out of 2500 personnel in the present study. No incidence of any other concurrent infection. This is not in correlation with the study of B Nkrumah mainly because of the above said reason.

Analysis of sex-related seroprevalence showed that the females were relatively more infected than the males. Although the difference was only slight among the police personnel and no statistically significant difference was observed. A study showing similar results of greater incidence in females was conducted by A. Al-Ajlan where a significantly greater proportion of female students were positive in both age groups and for both markers of $\mathrm{HBs} \mathrm{Ag}$ and anti-HCV compared to males. This difference can be attributed to the lesser number of females screened as compared to the males. Thus although the reactive cases were higher in males, the overall percentage showed that female personnel are more vulnerable to these infections. This is in contrast to the findings of Su et al.

The police personnel do not have an elevated seroprevalence of blood borne viruses when compared to general population. Our study revealed intermediate prevalence of the viral infections in police personnel with slightly greater prevalence of $\mathrm{HCV}$. This study encourages regular screening of Police personnel for the detection of the viral markers like the health care workers as they are also vulnerable to contracting these infections. We recommend total healthcare screening and medical management of all police personnel. In addition, proper information and technique should be taught to police personnel for handling causalities especially management of infectious material like blood as they are the first responders to mishaps. Public health policy must involve all sections of the community, including police personnel if we are to reduce transmission of HIV and other blood borne viruses.

\section{References}

Allian Jean-Pieree, Angela R, Kuhnus Mary C, Namara Anne MC. Clinical importance of $\mathrm{HCV}$ confirmatory testing in blood donors. The Lancet 339, 1992.

Deshpande A, Kumar A, Khodaiji S and Gupta AD. Prevalence of HCV antibody in healthy blood donors. Indian $\mathbf{J}$ Hematol and Blood Transf 16: 71-72, 1998.

Garg S, Mathur DR, Gard DK (2001) Comparison of seropositivity of HIV, $\mathrm{HBV}, \mathrm{HCV}$ and syphilis in replacement 
and voluntary blood donors in western India. Indian J Pathol. Microbiol., 44: 409-412.

Joshi SR Seropositive status for HIV infection among voluntary and replacement blood donors in the city of Surat from Western Indian. Indian $\mathrm{J}$ Hemat and blood Transf., 16: 20-21, 1998.

Kapur S and Mittal A. Incidence of HIV infection and its predictors in blood donors in Delhi, Indian $\mathbf{J}$ Med Research., 108: 45-50, 1998.

Kaur H, Dhanoa J, Pawar G (2001) Hepatitis $\mathrm{C}$ infection amongst blood donors in Punjab-a six year study. India J Hemat Blood Transf., 19:21-22

Kulkarni MG, Koppikar GV, Mehta PR, Borges NE. Seroprevalence of HIV-1 infection in Bombay (B321) in abstracts from the $2^{\text {nd }}$ International Congress on AIDS in Aisa and The Pacific No.92.

Pahuja S, Sharma M, Baitha B, Jain M (2007) Prevalence and trends of markers of hepatitis $\mathrm{C}$ virus, hepatitis $\mathrm{B}$ virus and humany immunodeficiency virus in Delhi blood donors. A hospital based study. Jpn J Inf Dis., 60: 389-391

Ramanamma MV and Rfamani TV. A Preliminary report on the seroprevalence of HIV-2 in Visakhapatnam. Indian J Med Microbiol., 12: 212-215, 1994.
Riyadh College of Health Sciences (Men), King Saud University, Saudi Arabia (Correspondence to A-R. Al-Ajlan): EMHJ, Vol. 17 No. 10, 2011.

Sarin SK, Saxena R, Sundaram KR, Transfusion associated hepatitis, risks and estimates in Indian population in transfusion associated hepatitis, Sarin SK, Hess G eds; I ${ }^{\text {st }}$ edn. CBs publishers and distributors, New Delhi., 212-218, 1998.

Singh K, Bhat S, Shastry S (2009) Trend in seroprevalence of Hepatitis B virus infection among blood donors of coastal Karnataka, India. J Infect Dev Ctries., 3:376-379

Srikrishna A, Sitalakshmi S, Damodar P (1999). How safe are our safe donors. Indian J Pathol. Microbiol., 42:411-416

$\mathrm{Su} \mathrm{FH}$ et al., Forecasting the declining rate of chronic hepatitis-B 15. carrier status at a Taiwanese university: twenty years after implementation of an universal HBV vaccination program in Taiwan. Chang Gung Medical Journal, 2007, 30:521528.

Tallaor Shashikala S, Shahapurkar A and Krishan BVS. Prevalence of HIV infection among blood donors in North Karnataka. Indian J Med Microbiol., 15: 123-125, 1997.

\section{How to cite this article:}

Priyanka Khanna, Jaspal Kaur and Kailash Chand. 2017. Seroprevalence of Human Immunodeficiency Virus, Hepatitis C Virus and Hepatitis B Virus in Police Personals. Int.J.Curr.Microbiol.App.Sci. 6(12): 928-934. doi: https://doi.org/10.20546/ijcmas.2017.612.101 